\begin{tabular}{|l|l|l||}
\hline \multicolumn{2}{|c|}{ PublisherInfo } \\
\hline \hline PublisherName & $:$ & BioMed Central \\
\hline \hline PublisherLocation & $:$ & London \\
\hline \hline PublisherImprintName & $:$ & BioMed Central \\
\hline \hline
\end{tabular}

\title{
Mice without rings
}

\begin{tabular}{|l|l|l||}
\hline \multicolumn{2}{|c|}{ ArticleInfo } \\
\hline \hline ArticleID & $:$ & 3834 \\
\hline \hline ArticleDOI & $:$ & $10.1186 /$ gb-spotlight-20001116-02 \\
\hline \hline ArticleCitationID & $:$ & spotlight-20001116-02 \\
\hline \hline ArticleSequenceNumber & $:$ & 271 \\
\hline \hline ArticleCategory & $:$ & Research news \\
\hline ArticleFirstPage & $:$ & 1 \\
\hline \hline ArticleLastPage & $:$ & 2 \\
\hline \hline & $:$ & RegistrationDate : 2000-11-16 \\
ArticleHistory & $:$ & OnlineDate \\
\hline \hline ArticleCopyright & $:$ & BioMed Central Ltd2000-11-16 \\
\hline \hline ArticleGrants & $:$ & \\
\hline \hline ArticleContext & $:$ & 130591111 \\
\hline \hline
\end{tabular}




\section{Jonathan Weitzman}

Email: jonathanweitzman@hotmail.com

The Polycomb group (PcG) genes encode trans-acting regulators of homeotic gene expression patterns in Drosophila. Homologs of Drosophila PcG products have been identified in plants and mice. There is substantial biochemical evidence that the Ring1 A protein is part of a mammalian multi-subunit PcG complex. It is, however, the only mammalian PcG gene for which there is no fly homolog identified and there is no proof of a PcG function for Ring1A. In the 2 November Development, Lorente et al. report the generation of loss- and gain-of-function alleles of murine RINGIA to investigate its role in vivo (Development 2000, 127:5093-5100). Ring1A-/- knockout mice exhibit homeotic transformations and skeletal abnormalities. Lorente et al. report that Ring1A deficiency leads to anterior transformations, in contrast to the posterior effects of other PcG mutations in mice. Heterozygote Ring1 A+/- animals show similar abnormalities, suggesting that dosage requirements for Ring1A are more critical than for other PcG genes. Finally, overexpression of Ring1 A causes axial skeleton defects, showing the amount of Ring1 A expression is important.

\section{References}

1. The Polycomb and trithorax group proteins of Drosophila: trans-regulators of homeotic gene function.

2. A Polycomb-group gene regulates homeotic gene expression in Arabidopsis.

3. Functions of mammalian Polycomb group and trithorax group related genes.

4. Development, [http://www.biologists.com/Development]

This PDF file was created after publication. 